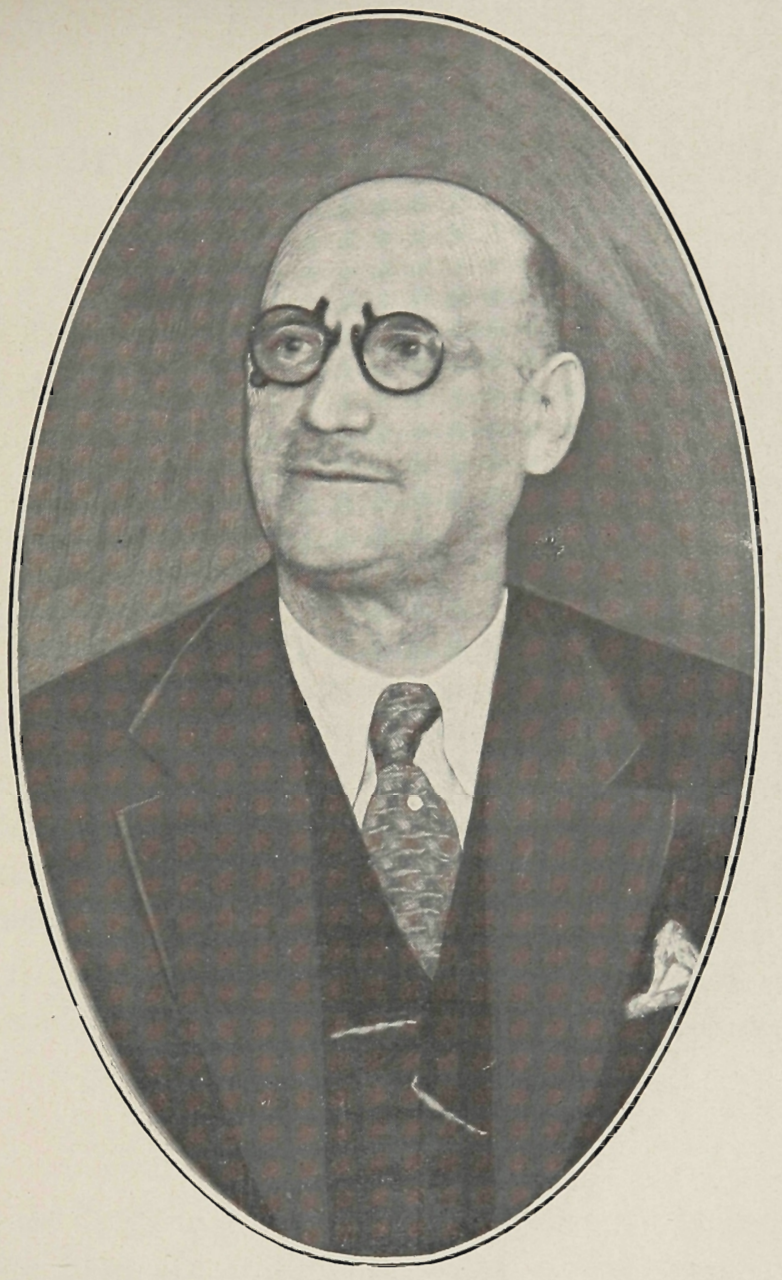

Professor RAPHAEL CORREA DE SAMPAIO 


\section{Professor Raphael Corrêa de Sampaio}

Com o falecimento do professor Raphael Sampaio, ocorrido a $\mathbf{1 0}$ de novembro findo, sofreu a Faculdade de Direito profundo golpe.

Distinguia-se aquele Mestre pela particular dedicação, incessante através de longo tirocínio, que consagrava á Academia, sob todos os aspectos da sua atividade.

Era, na Congregação, o guarda fiel das tradições do glorioso instituto, pelas quais sempre zelou com afeto, que o perpassar dos anos redobrava.

Poucos dias antes da infáusta ocorrência, instado pelos colegas a deixar por alguns dias os trabalhos acadêmicos, para dedicar á saúde abalada os cuidados por éla requeridos, respondeu o professor Raphael Sampaio que preferia morrer no seu posto.

E aí o colheu a morte, quando, no Doutoral, e perante a Congregação, arguia um dos candidatos á livre docência.

Filho de Geraldo Augusto de Sampaio e D. Isabel Maria de Azevedo Sampaio, ambos de velha estirpe paulista, nasceu o Professor Raphael Sampaio em Pirassununga, dêste Estado, a 21 de dezembro de 1873.

Concluidos os preparatórios no antigo Curso Anexo, ingressou na Faculdade, e, durante o curso acadêmico, professou humanidades no Colégio Paulista e redigiu o jornal "A República" 
Recebendo gráu em Ciências Jurídicas e Sociais a 3 de dezembro de 1896, passou a dedicar-se á advocacia, e á dire ção da "Gazeta Jurídica", onde brilhavam Duarte de Azevedo, João Monteiro, Raphael Corrêa, Souza Lima, Pedro Lessa, Aureliano Coutinho, João Mendes Junior, Brasilio Machado, Ferreira Alves, e outros espíritos de escol.

Exerceu também, com grande proficiência, o cargo de Promotor Público nesta Capital.

A 19 de abril de 1911 foi nomeado lente substituto da 1." Secção, passando mais tarde a reger, como professor efetivo, a cadeira de Direito Judiciário Penal.

Foi Presidente do Conselho da Caixa Econômica Federal em São Paulo, e, durante varias legislaturas, representou o povo, como deputado e como senador, no Congresso Legislativo do Estado.

Foi membro da Comissão Diretora do Partido Republicano Conservador, e da do Partido Republicano Paulista.

Tomou parte saliente na elaboração do Projeto do atual Código do Processo Civil e Comercial do Estado, como membro da Comissão respetiva.

Era mordomo na Santa Casa de Misericórdia de São Paulo, e membro do Conselho Penitenciário do Estado. 